\title{
The Impact of Internal Factor Analysis Summary (IFAS) and Competing Power on Performance in the Life Insurance Industry: The Mediating Role of Competitive Advantage
}

\author{
Ratna Dewi \\ Lecturer in Management Science, Muslim University of Indonesia, Indonesia \\ Amir Mahmud \\ Lecturer in Management Science, Muslim University of Indonesia, Indonesia
}

Received: April 11, 2018

doi:10.5296/wjbm.v4i1.13272
Accepted: May 22, 2018

Published: May 30, 2018

URL: https://doi.org/10.5296/wjbm.v4i1.13272

\begin{abstract}
This research aim to test and analyze the impact of internal factor analysis summary (IFAS) and competing power on performance in the life insurance industry in Makassar (Indonesia): The mediating role of competitive advantage. This study uses 60 employees of insurance companies at the manager level. Path analysis results provide evidence that the internal factor analysis summary (IFAS) and competitiveness significantly influence the competitive advantage and performance in the life insurance industry. The role of competitive advantage proved able to mediate the effect of internal factor analysis summary (IFAS) in improving the performance in the life insurance industry. The different conditions with competitive advantages that cannot increase the competing power against performance in the life insurance industry
\end{abstract}

Keywords: IFAS, Competing power, Competitive advantage, Performance 


\section{Ml Macrothink}

\section{Introduction}

The development of the business world in the service sector today has experienced a dynamic increase over the previous decade. The increase is due to increased welfare and income per capita community. This dynamic is characterized by the development of service industries such as banking, insurance, aviation, telecommunications, retail, tourism, and professional service firms such as accounting firms, consultants and lawyers. Insurance has an important role in the Indonesian economy, although it seems slow because it is generally only in demand by industry and trade sectors. The condition is relevant to Indonesia's rating in the field of insurance globally. In a global context based on the number of life insurance premiums, Indonesia ranks 37th place while for general insurance premiums Indonesia is ranked 44 out of 88 countries analyzed in World Insurance Outlook. Indonesia occupies a better position compared to the Philippines and Vietnam for premium and insurance penetration, but for Insurance density ranking Indonesia lower compared to the Philippines and Vietnam. The three relatively advanced Asian countries of its insurance industry are Japan, South Korea, and Taiwan. All three countries have a value of life insurance premiums are relatively large so that it takes 10 of the world, although for general insurance only Japan and South Korea are in the top (World Insurance Outlook, 2012)

Table 1. World's top insurers ranked by premium life insurance

\begin{tabular}{|l|c|c|c|c|}
\hline \multicolumn{1}{|c|}{ Country } & Life & Non-Life & Penetration & Density \\
\hline United States & 1 & 1 & 14 & 6 \\
\hline Japan & 2 & 4 & 7 & 9 \\
\hline United Kingdom & 3 & 1 & 1 & 1 \\
\hline France & 4 & 5 & 6 & 5 \\
\hline Germany & 5 & 2 & 22 & 17 \\
\hline South Korea & 7 & 9 & 4 & 21 \\
\hline China & 8 & 11 & 47 & 70 \\
\hline Taiwan & 9 & 18 & 3 & 20 \\
\hline India & 12 & 26 & 31 & 76 \\
\hline Hong Kong & 20 & 41 & 8 & 14 \\
\hline Singapore & 20 & 41 & 23 & 22 \\
\hline Malaysia & 28 & 34 & 29 & 41 \\
\hline Thailand & 33 & 37 & 37 & 57 \\
\hline Indonesia & 37 & 35 & 74 & 78 \\
\hline \multicolumn{1}{|c|}{ Country } & Life & Non-Life & Penetration & Density \\
\hline Philippines & 41 & 55 & 73 & 80 \\
\hline Vietnam & 49 & 71 & 72 & 84 \\
\hline
\end{tabular}




\section{Mll Macrothink}

World Journal of Business and Management

ISSN 2377-4622

2018, Vol. 4, No. 1

Table 1 shows interesting facts such as the Chinese country which is ranked 8th for the category of premium value and for the non-soul category of China is ranked 11th, but as the most populous country in the world, China for the category of insurance density is on ranking the world 70. This condition is similar to that in other countries with the largest population in the world such as India and Indonesia. Based on these facts it can be concluded that the low ranking of Indonesia in the insurance sector is more due to the total premium and gross domestic product (GDP) is much lower than China. The high interest of the business world in the field of insurance services is a major concern for scholars to undertake various strategic analyzes for the development of this sector, insurance businesses are expected to review their plans to adjust to the competitive market.

The main factor of the company's success lies in the company's ability to understand the environment in which the company operates, the company is required to be able to estimate the changes that occur in its environment and the company is required to be able to assess the consequences of changes that occur to the company's operations. The company is required to make decisions about its products, the prices it offers and how a product can be promoted and distributed (Goodwin, 1994). The power of competition occurs when two or more companies are fighting over each other in their pursuit of a profitable market position. Increasingly competitive competition takes place between companies because one or more competitors feel pressure or see opportunities to improve the company's market position.

Competition is made possible by the competitive asymmetry that occurs when firms differ from each other in resources, capabilities, and core competencies (Hitt et al., 2001). The five strategic strengths of the company include; (1) potential for entry of new competitors, (2) bargaining power of suppliers, (3) consumer bargaining power, (4) potential development of replacement products, and (5) competition between rival companies (Porter, 2008). Another view of scholars explains that competitive advantage is superior to competitors obtained by offering lower value or greater benefit because of higher price (Amstrong \& Kotler, 2003). This view is relevant to other scholars' claims that core competence is the resource and capability that are the source of competitive advantage for the company, beyond its competitors. As a source of competitive advantage for corporations, core competencies differentiate firms competitively and reflect their personalities (Hitt et al., 2001).

Applying innovation and marketing creativity can improve business and achieve competitive advantage. To achieve the benefits of competitive supported by three factors, namely (1) efficiency, is the ability of the company in assessing the work of employees based on the production and services produced include the development of production and services, (2) quality of products and services are products produced high quality and service can affect the position of the company's competitive advantage, and (3) customer satisfaction is the level of one's feelings after comparing perceived results compared with expectations (Epetimehin, 2011).

Insurance companies can use the collaboration to achieve competitive advantage. Collaboration is a process of cooperation to achieve goals and is an integral part of the insurance business. The power of integrating for collaboration is done by: (1) content is all 
collaboration begins with information, and information is converted into digital content. Modern management systems show that content not only provides basic repositories, but also workflows and businesses. (2) Poses management is a process done in order for collaboration to be optimized, process and content must be governed by automated systems (Breading, 2014).

Another vital role for the continuation of highly competitive growth in global markets can be accomplished by performance measurement. A company's performance is often measured as the ratio of output to input. Output is a product of the company and input is the resource used by the company. All real and good factors intangible should be included in the organization's performance analysis. Performance or performance is a picture, regarding the level of achievement of the implementation of an activity or policy program in realizing organizational goals, goals, vision and mission as outlined through strategic planning of an organization (Garengo et al., 2005; Choudhary, 2012). Performance can be identified and measured if an individual or group of employees has defined criteria or standards of success of the benchmarks set by the organization, such as (1) work, (2) behavior, (3) attributes and competencies, and (4) comparative (Moeheriono, 2012).

Various empirical phenomena on the concept of views that can be used in analyzing organizational performance so that it becomes a gap and become the motivation of the researcher is; (1) increasingly intense global competition, has motivated to analyze internal environmental factors, Competing Strength, and Competitive Advantages to improve company performance, (2) issues developed in relation to the amount of policy costs for once claims to make the community interested to use the insurance company, and (4) this study not only complements competitive advantage (Porter, 2008), but complements the findings of previous researchers by applying strategic measurement models using internal factors analysis summary (IFAS), strength and competitive advantage (5) limited theoretical basis to justify the measurement of Internal Factors Analysis (IFAS); (6) the measurement of competitive advantage indicates that there are inconsistencies caused by the diversity of industry dimensions and characteristics in measuring company performance and competitive advantage as measured by efficiency, product quality, service quality and customer satisfaction (Epetimehin, 2011), (7) still limited empirical studies that tested the influence of Internal Factors Analysis Summary (IFAS).

\section{Methods}

This study was conducted for four months in the Year 2015 at 30 life insurance companies in Makassar City 2015, each life insurance company withdrawn 2 people at the manager level so that the total sample used 60 Managers. There are 14 of them whose data are flawed so that they cannot be included to be analyzed so that the total data used is 46 respondents. The design of this study using explanatory research that means explaining the position of variables studied and the relationship and influence between one variable with other variables (Sugiono, 2004). The data were collected using observation method, interview and questionnaire. The collected data is processed using a quantitative descriptive analysis tool. Data analysis was done by utilizing Path Analysis (Solimun, 2002; Bahar \& Sjahruddin, 
2017), through formulation:

$$
\begin{array}{ll}
\mathrm{Y}_{1} & =\beta_{10}+\beta_{11} \mathrm{Y}_{2}+\mathrm{Y}_{11} \mathrm{X}_{1}+\mathrm{Y}_{12} \mathrm{X}_{2}+\mathrm{e}_{1} \\
\mathrm{Y}_{2} & =\beta_{20}+\beta_{2} \mathrm{Y}_{21}+\beta_{3} \mathrm{Y}_{22}+\mathrm{e}_{2} \\
\text { Where : } & \mathrm{Y}_{2}=\text { Performance } \\
& \mathrm{Y}_{1}=\text { Competitive advantage } \\
& \mathrm{X}_{1}=\text { IFAS } \\
& \mathrm{X}_{2}=\text { Competing power } \\
& \beta_{1}-\beta_{3}=\text { Regression Weight } \\
& \mathrm{e}_{1}-\mathrm{e}_{2}=\text { Disturbance Term }
\end{array}
$$

\section{Results}

\subsection{Respondents Characteristic}

Explanation of respondent characteristics is explained through position, age, gender, length of service, and education level. For it is presented below:

Table 2. Characteristics of respondents

\begin{tabular}{lcc}
\hline Characteristics & Frequency $(\mathrm{n}=46)$ & Percent \\
\hline Gender & & \\
Male & 26 & 56.52 \\
Female & 20 & 43.48 \\
Ages & & \\
21-30 Years & 4 & 8.70 \\
31-40 Years & 27 & 58.70 \\
41-50 Years & 14 & 30,43 \\
$>$ 51 Years & 1 & 2.17 \\
Functional level & & \\
Branch Manager & 12 & 26.09 \\
Agency Manager & 20 & 43.48 \\
Operational Manager & 14 & 30.43 \\
Job tenure & & \\
6-10 Years & 10 & 21.74 \\
11-15 Years & 19 & 41.30 \\
$>16$ Years & 17 & 36.96 \\
Educational level & & \\
Master of science & 3 & 6.52 \\
Bachelor & 35 & 76,09 \\
Diploma & 8 & 17,39 \\
\hline
\end{tabular}


Respondent based on gender was male with 26 people $(56,52 \%)$, then based on age of respondent dominated by age 31 - 40 year counted 27 people $(58,70 \%)$. Furthermore, based on the most functional positions is Agency managers are as many as 20 people (43.48\%). Based on the period of work, respondents are characterized by the working period of $11-15$ years, 19 $(41,30 \%)$ and most of them have the final education of Bachelor as many as 35 people (76, 09\%).

\subsection{Descriptive Variables}

\subsubsection{Internal Factors Analysis Summary (IFAS)}

Internal Factor Analysis Summary (IFAS) is an analysis of various internal factors that affect the sustainability of a company. IFAS identification is done by looking at the internal condition of the insurance and into consideration when management formulates and implements the company's strategy. The average score of respondents is 4.25 which are characterized by financial ability (4.32), marketing ability (4.14), operational ability (4.30), human resource capacity (4.27), and management capability (4.23). These results indicate that the role of IFAS is quantitatively strongly supported by financial capacity, operational capability and human resource capability. The condition is relevant to the undergraduate assertion that internally the company must have the ability to manage resources, whether marketing capabilities, human resources, production or machine capacity, finance, and the availability of relevant accounting information (Pearce \& Robinson, 2007).

\subsubsection{Competing Power}

Competing power occur when there are two or more companies pursuing mutually beneficial market positions. Competitive value occurs between companies because one or more competitors feel pressure or see opportunities to improve the company's market position. The average score of respondents is 4.30. This condition is indicated by Competition for Newcomers (4.41), Consumer Bargaining (4.28) and Competition among competitors (4.37).

\subsubsection{Competitive Advantage}

Competitive advantage is a company's ability to effectively anticipate reacting and leading continuous change from time to time. Construction of competing forces has an average value of 4.22 that can be measured by five indicators referring to indicators for measuring competing forces of efficiency (4.17), product Quality (4.30), service quality (4.53), Collaboration (4.17), and Communication (3.95).

\subsubsection{Performance}

Performance is a description of the level of achievement of the implementation of an activity or policy program in realizing the goals, objectives, vision and mission of the organization as outlined through strategic planning organization or company. The company performance contributes the mean value of 4.30 measured by employment (4.41), behavior (4.26), attributes and competencies (4.37), and comparative (4.38). 


\section{Results}

\subsection{Effect of IFAS on Competitive Advantages}

The influence of internal factor analysis summary (IFAS) of competitive advantage can be proved by the value of regression coefficient equal to 0,335 and probability value equal to $0,008<\alpha=0,05$, so it can be concluded that the application of internal factor analysis summary (IFAS) proven to increase competitive advantage. The implementation of IFAS contributes greatly to the increased competitive advantage in the insurance services industry in Makassar.

The results of this study support the concept of internal environment that includes resources, capabilities, and core competencies. Decision-making by managers on core resources and core competencies has a significant influence on firms' ability to develop competitive advantage and receive returns above average (Hitt et al., 2004). IFAS emphasizes the marketing capability of selling insurance products by delivering value to consumers as expected, and management capabilities in determining the direction of corporate objectives, planning, managing, and managing corporate leadership (Domingo et al., 2017). The results of this study are relevant to the statement of scholars that internal analysis as a critical support to the effectiveness of management strategies and the use of resources should be effected effectively (Peearce \& Robinson, 2000). That internally the company has the ability to manage its resources, such as marketing ability, human resources, and finance, as well as the availability of relevant accounting information. Competitive advantage is the company's ability to effectively anticipate, react and lead change continually every time.

This study proves that the company's success in analyzing IFAS and improving strategy that focuses on product strategy using customer value approach by offering various insurance policies is strongly supported by skilful employee. Without the support of operational capability and human resources and the company's desire to constantly improve on its marketing capabilities and management capabilities, IFAS is unable to contribute significantly to the creation of competitive advantage. This is reflected by high employee involvement in formulating and implementing company strategy well. The application of IFAS and the efforts of all employees trained in the marketing of insurance services provide relevant impacts, so that consumers are interested in purchasing an insurance policy.

\subsection{Effect of Competing Power on Competitive Advantage}

The effect of competing power of competitive advantage can be proved by the value of regression coefficient of 0.300 and probability value of $0.014<\alpha=0.05$, so it can be concluded that the competing forces shown by the company proved to increase competitive advantage. The results of this study prove that competing forces significantly influence the competitive advantage in the life insurance industry services company in Makassar. This study supports the concept of competitive advantage proposed by Porter (2008) that the nature of competition in a particular industry can be seen as a combination of five strengths, namely: (1) potential entry of new competitors, (2). Supplier bargaining power, (3) Consumer bargaining power, (4) Potential development of replacement products, and (5) Competition 
among rival firms (Anagol et al., 2017).

The results of descriptive analysis show that the competition of newcomers is the main indicator in reflecting the variables of competing power. This is evident from the higher mean values of other competitive strength indicators. This situation illustrates that the Insurance industry places great emphasis on the competition of new entrants in the preparation of strategies to identify new insurance companies entering the market, utilizing the strengths and opportunities available to acquire customers and implementing strategies faster than rival firms. Consumer bargaining power and competition among competitors illustrates that the life insurance industry in Makassar City is very concerned about the bargaining power of consumers to improve competition among competitors Competition among rival companies is usually the most powerful of the five competitive forces. It can therefore be interpreted that to achieve competitive advantage a company-run strategy can succeed with the consequence that a firm must generate competitive power over a competitor's strategy. Changes in the strategy by the company can be responded with counter measures, such as price reductions, improved product quality, service delivery, and intensive advertising. The intensity of competition between rival companies tends to increase as the number of competitors increases, when competitors have the appropriate size and capability.

\subsection{Effect of IFAS on Performance}

Contributes the IFAS on performance can be proved by the value of regression coefficient of 0.264 with a positive direction and probability value of $0.045<\alpha=0.05$, so it can be concluded that the implementation of IFAS proved to improve the performance of the company. The results of this study contradict the findings of a research by Ingga (2008), that the internal environment positively and significantly influences the cost leadership strategy, but not significantly to the differentiation strategy and competitive advantage. This study is relevant to the findings of other researchers (Wibowo et al., 2017). This finding identifies those internal environments with cost leadership strategies are interrelated components. The results of this study provide relevant information in various decision-making for the management company. Marketing ability, human resource capability, marketing ability, financial ability becomes the centre of attention of the company.

\subsection{Effect of Competitive Power on Performance}

Performance is a description, about the level of achievement of the implementation of an activity or policy program in realizing the goals, objectives, vision and mission of the organization as outlined through strategic planning of an organization. The influence of competing power on company performance can be proved by regression coefficient value equal to 0.250 with positive direction and probability value of $0,043<\alpha=0,05$, so it can be concluded that competing power proved can improve company performance. Life insurance companies in Makassar City have a high competitive power so that the company's performance increases. This research supports the concept of corporate strength (Porter, 2008), that the firm's strength is the interaction of the five forces, namely (1) Potential entry of new competitors, (2) Bargaining power of suppliers, (3) Consumer bargaining power, (4) substitute products, and (5) Competition among rival companies (Nofrizal, 2017). The 
company's success combines the three competitive power indicators shown in the competition indicators of new entrants forming a competitive power, that the company in the strategist identifies the newly entered insurance companies and takes advantage of the strengths and opportunities available to the customer. High competitive power will ultimately improve the company's performance. This is evidenced by the success of employees in the work shown through the amount of receipts, premiums, marketing activities and profit levels obtained.

\subsection{Effect of Competitive Advantage on Performance}

The effect of competitive advantage on performance can be proved by the value of regression coefficient of 0.264 with a positive direction and probability value of $0.029<\alpha=0.05$, so it can be concluded that competitive advantage proved to improve company performance. The results confirm that competitive advantage positively affects the firm's performance. This means that the company's performance will be achieved if the company has competitive advantage. The research results support findings Epetimehin (2011), which through marketing innovation and creativity have become the authorized capital of the insurance industry in improving their business performance. Competitive advantage can improve business performance, meaning that competitive advantage based on descriptive analysis is reflected through dominant communication indicators forming competitive advantage variables so the company has the ability to publish, promote new business and products.

\subsection{The Mediating Role of Competitive Advantages: The Effect of IFAS on Performance}

The effect of IFAS on company performance with competitive advantage as mediation can be proved by regression coefficient value equal to 0.088 with a positive direction and probability value of $0.005<\alpha=0.05$, so it can be concluded that competitive advantage proved as mediation in analyzing the influence of IFAS on company performance. This condition is because the company has a high ability in doing a combination of internal and external factors, that the company has an advantage in knowing the strengths, weaknesses, opportunities, and treats facing the business world. the results of this study support the findings of previous research, that with the support of competitive advantage owned by the company, the contribution of IFAS implementation is better so that company performance can be improved (Freddy, 2003; Leonidou et al., 2011).

\subsection{The Mediating Role of Competitive Advantages: The Effect of Competing Power on Performance}

The effect of competing power on company performance with competitive advantage as mediation can be proved by the value of regression coefficient 0.085 with a positive direction and probability value of $0.456<\alpha=0.05$, so it can be concluded that the competitive advantage is not proven as a mediation in analyzing the influence of competing forces on the performance of the company. Determining the right strategy of competitive advantage will have an impact on the company's performance when the company is able to meet consumer expectations, so that the competitiveness of the company is able to increase competitiveness and ultimately impact on high performance of the company. The results of this study support the findings of Yadav et al. (2017) that consumer satisfaction is proven to mediate the 
influence of competing forces with business performance (Theodosiou \& Katsikea, 2013).

\section{Conclusion}

The successful implementation of IFAS is reflected by the financial ability, operational capability and human resource capability, so that the company is able to improve efficiency, product quality, service quality, collaboration and communication as a form of competitive advantage and company performance. The potential for entry of new competitors, bargaining power of suppliers, and competition between rival companies becomes the leverage of competing forces resulting in high competitive advantage. High achievement of company performance is done by interaction on the work, attribute and competence, comparative and behaviour.

The role of competitive advantage mediation proves to be able to support the contribution of IFAS implementation in an effort to improve company performance, this condition is inversely proportional to the competitiveness, that the competitive advantage is not able to make a significant contribution in the improvement of company performance caused by the company's competing power. Life insurance services company in Makassar City as far as possible maintain internal factor analysis so that company more survive and able to compete in global market. Consumers' bargaining power needs to be a concern for companies, to have strong competitive forces it is advisable that companies should choose appropriate marketing strategies, such as growth strategies. Management capabilities are the weakest indicators that make up IFAS so it is recommended that management further improve management capabilities in management planning, management and control.

Life insurance companies in their management have various problems that hamper their growth due to the people's lack of trust in life insurance companies. To the government as the determinant of the regulation of the national business world to always pay attention to the problems faced by the life insurance industry sector in Makassar City, because with the attention of the government, the life insurance industry is able to encourage the national economic growth.

\section{References}

Anagol, S., Cole, S., \& Sarkar, S. (2017). Understanding the advice of commissions-motivated agents: Evidence from the Indian life insurance market. Review of Economics and Statistics, 99(1), 1-15. https://doi.org/10.1162/REST_a_00625

Armstrong, G., \& Kotler, P. (2003). Fundamentals of Marketing (Vol. 1, 9th ed.). Jakarta: Gramedia Index

Bahar, A., \& Sjahruddin, H. (2017). The effect of product quality and Servqual on Consumer Satisfaction and repurchase intention

Brending, M. (2014). Interactive Intelligence, How Insures can us Colaboration for a Competitive Advantage. Inc. All Rigts Reserve

Choudhary, R. K. (2012). Key organizational factors in data warehouse architecture selection. 
Vivekananda Journal of Research, 1(1), 24-32.

Domingos, U. S., Silva, J. C. M., \& Pereira, J. A. (2017). On the use of quality function deployment matrix for flexible and quantitative prioritization. Journal of Advanced Management Science, (5), 401-408.

Epetimehin, F. M. (2011). Achieving competitive advantage in insurance industry: The impact of marketing innovation and creativity. Journal of Emerging Trends in Economics and Management Sciences (JETEMS), 2(1), 18-21.

Freddy, R. (2003). SWOT Analysis Techniques Dissecting Business Cases. Jakarta. Gramedia Pustaka Utama.

Garengo, P., Biazzo, S., \& Bititci, U. S. (2005). Performance measurement systems in SMEs: A review for a research agenda. International Journal of Management Reviews, 7(1), 25-47. https://doi.org/10.1111/j.1468-2370.2005.00105.x

Goodwin, D. W. (1994). Life and Health Insurance Marketing. LOMA (Life Office Management Association, Inc.).

Hitt, M. A., Ahlstrom, D., Dacin, M. T., Levitas, E., \& Svobodina, L. (2004). The institutional effects on the strategic alliance partner selection in transition economies: China vs. Russia. Organization Science, 15(2), 173-185. https://doi.org/10.1287/orsc.1030.0045

Hitt, M. A., Ireland, R. D., \& Hoskisson, R. E. (2001). Strategic Manajement: Competitiveness and Globalization. Jakarta, Salemba Four.

Ingga, I. (2008). The effects of external environments, internal environments, cost leadership strategies, and differentiation strategies on customer value and competitive advantage. Unpublished dissertation. Brawijaya University, Malang

Leonidou, L. C., Palihawadana, D., \& Theodosiou, M. (2011). National export-promotion programs as drivers of organizational resources and capabilities: Effects on strategy, competitive advantage, and performance. Journal of International Marketing, 19(2), 1-29. https://doi.org/10.1509/jimk.19.2.1

Moeheriono. (2012). Competency Based Performance Measurement. Jakarta: King. Grafindo Persada

Nofrizal, N. (2017). Growing and Competing Strategies in Insurance Industry (Case Study At Employment BPJS Pekanbaru). Benefit: Management and Business Journal, 2(1), 78-91. https://doi.org/10.23917/benefit.v2i1.3691

Pearce \& Robinson. (2007). Management Strategy. Salemba Four, Jakarta.

Porter, M. E. (2008). Competitive strategy. Tangerang: Karisma publishing group.

Solimun. (2002). Structural Equation Modeling LISREL and Amos. Faculty of Mathematics and Natural Sciences Brawijaya University. Malang.

Sugiyono. (2004). Business Research Methods: CV Publisher. Alfabeta: Bandung. 


\section{Macrothink}

World Journal of Business and Management

ISSN 2377-4622 2018, Vol. 4, No. 1

Theodosiou, M., \& Katsikea, E. (2013). The export information system: An empirical investigation of its antecedents and performance outcomes. Journal of International Marketing, 21(3), 72-94. https://doi.org/10.1509/jim.12.0165

Wibowo, S. S. A., Handayani, Y., \& Lestari, A. R. (2017). Company's competing strategy and company performance. Indonesian Accounting and Financial Research, 2(2), 42-50.

Yadav, P. L, Han, S. H., \& Kim, H. (2017). Sustaining competitive advantage through corporate environmental performance. Business Strategy and the Environment, 26(3), 345-357. https://doi.org/10.1002/bse.1921

\section{Copyright Disclaimer}

Copyright for this article is retained by the author(s), with first publication rights granted to the journal.

This is an open-access article distributed under the terms and conditions of the Creative Commons Attribution license (http://creativecommons.org/licenses/by/3.0/). 